\title{
Estimation of Total Dissolved Solids in Water Bodies by Spectral Indices Case Study: Shatt al-Arab River
}

\author{
Ali A. A. Maliki • Ali Chabuk • Maitham A. Sultan • \\ Bassim M. Hashim • Hussain M. Hussain • \\ Nadhir Al-Ansari 1 (
}

Received: 20 June 2020 / Accepted: 25 August 2020 / Published online: 5 September 2020

(C) The Author(s) 2020

\begin{abstract}
In recent years, the problem of rising salinity levels in the Shatt al-Arab river in southern Iraq has been repeated, which has directly affected the living and health situation and the agricultural activity of these areas. Six sampling stations were selected along Shatt al-Arab to estimate the concentration of total dissolved solids (TDS) in the river; these stations included the following: Qurna, Labani, City Centre, Kateban, Corniche, and Sihan. In addition, three Landsat- 8 satellite images which were taken at the same time as collected samples also used for detecting the salinity in the river. After processing of atmospheric correction and inserted

Featured Application: Total dissolved solids (TDS) is an important water quality parameter that can be monitored regularly more easily by remote sensing techniques. This study aims to use satellite images to determine TDS values, in water bodies. This study was applied on Shatt al-Arab river, southern Iraq (as a case study). Remote sensing with spectral index algorithms will ease the monitoring task very efficiently by saving time and resources
\end{abstract}

A. A. A. Maliki · M. A. Sultan · B. M. Hashim

Ministry of Science and Technology, Baghdad 10001, Iraq

A. A. A. Maliki

e-mail: alyay004@mymail.unisa.edu.au

M. A. Sultan

e-mail: maitham_nlt@yahoo.com

B. M. Hashim

e-mail: bassim_saa22@yahoo.com remote sensing indices, the reflectance of water extracted from satellite images was used to express the spectral characteristics of different TDS concentrations. Correlation and regression were used to obtain accurate models for detecting the salinity depending on the spectral reflectance of Landsat 8 operational land image OLI. The results presented Pearson correlation $(r)$ value of $0.70,0.97$, and 0.71 , and correlation coefficient $\left(R^{2}\right)$ of $0.56,0.94$, and 0.85 between field data with spectral data of salinity index 2 (SI-2) derived from the green and blue bands of Landsat obtained in 2015, 2017, and 2018 respectively. In conclusion, remote sensing and

\footnotetext{
A. Chabuk

Department of Environment Engineering, College of Engineering, University of Babylon, Babylon 51001, Iraq e-mail: ali.chabuk@uobabylon.edu.iq

H. M. Hussain

Remote Sensing Center, University of Kufa, Najaf, Iraq e-mail: hussainm.alshimmary@uokufa.edu.iq

N. Al-Ansari $(\square)$

Department of Civil, Environmental and Natural Resources Engineering, Lulea University of Technology, 97187 Lulea, Sweden

e-mail: nadhir.alansari@1tu.se
} 
GIS technologies coupled with spectral modeling are useful tools for providing a solution of future water resources planning and management, and also offer great undertaking as a means to improve knowledge of water quality and support water decision making.

Keywords Shatt al-Arab · GIS, remote sensing . Landsat-8 OLI $\cdot$ Salinity indices $\cdot$ Spectral index

\section{Introduction}

Salinity usually refers to a significant concentration of mineral salts in soil or water because of the hydrological processes (Schofield et al. 2001). There are two main types of salinization. The first type occurs through the natural processes, such as flood and storm surge. The second type occurs due to poor management practices, e.g., excessive use of fertilizer (Wu et al. 2008). TDS and salinity levels are much-related concepts as the most dissolved solids typically consist of inorganic ions, which are the components of salts; therefore, the reason for increasing salinity is similar to increasing TDS of surface water body (Ferdous et al. 2019).

A great deal of work has been carried out on the measurement of the salinity using remote sensing data, such as Multispectral Sensor (MSS), Thematic Mapper ( TM), Advanced Very High-Resolution Radiometer(AVHRR), High-Resolution Visible (HRV), and Moderate Resolution Imaging Spectroradiometer (MODIS) (Hellweger et al. 2004). Shatt al-Arab river is regarded as one of the most important rivers in Iraq and the main source of freshwater in the Al Basra province, southern Iraq, its water used for various purposes: drinking, irrigation, fisheries, navigation, and industry. Al Basra province has experienced severe degradation in its drinking water quality both in terms of salinity and TDS level. The water of Shatt al-Arab is suffering from water sources shortage or drying up; it is also being heavily impacted by sea-level rise and climate change effects. This has made the decline in quantity and quality of freshwater, drought, and salinity more severe. Also, it may be esthetically unsatisfactory for domestic uses like bathing and washing (Lim et al. 2009). The TDS level of the water body is increasing and becoming unacceptable, and it is expected to continue with severe degradation shortly. For example, TDS differed from 1985 to $7131 \mathrm{mg} / \mathrm{L}$ from December 2011 to November 2012 in some part of the river (Mohamed et al. 2016). Traditional water quality monitoring methods involve sampling and laboratory measurements of physical and chemical properties. These analyses are time-consuming and expensive. The solid-state sensors using metal oxide nanostructures are pointed out as a wireless sensor networks to provide a promising alternative to the contemporary timeconsuming analytical methods of water quality analysis [6]. However, it still requires envisaged much more advancement in order to enhance the sensing performance of the sensors. On the other hand, water management now requires an effective tool for developing solutions for water resources problems in large scale. The geographical information system (GIS) with remote sensing (RS) has become a necessary technique to study environment and water quality. These techniques provide powerful analytical and visualization tools for describing, analyzing, and modeling the natural system process and make the monitoring task very effective in terms of time and resources (Ferdous et al. 2019). The optical characteristics of water depend on its properties and it can be altered by a variation on the concentration and character of suspended and dissolved solids and other organic matters etc. (Ferdous et al. 2019). A significant amount of researches such as Hellweger et al. (2004); Lim et al. (2009); Karakaya et al. (2011); Kulkarni (2011); Yusop et al. (2011); Pásler and Komárková (2016); González-Márquez et al. (2018) have been conducted to manage water resources and detect water quality parameters in surface or groundwater, like the presence of metal ions, total suspended solids, total dissolved solids, and turbidity from different satellite images. The Landsat images have been applied in monitoring the Earth's surface and detecting soil, plant, and water features. Image enhancement led to converting of the image quality to be more understandable level for feature extraction. Different RS features are often used for identifying and monitoring properties of surface water and soil such as aerial photographs, video images, infrared (IR) thermography, visible (VIS) and infrared multispectral, and microwave images (Zhuiykov 2012). Several authors have demonstrated the advantage of combining satellite image analysis with field data to assess the accuracy of water quality detection (Lyon et al. 1988; Mohamed et al. 2016; Howari 2003; Härmä et al. 2001). Hence, many researchers have developed several numerical models to develop RS methods and spectral indices (Härmä et al. 2001; Dogliotti et al. 2015). These methods range from 
empirical algorithm to analytical methods for estimating and producing quantitative or qualitative water maps (Härmä et al. 2001). However, none of the previous studies used the technique of salinity indices from spectral images for detecting and monitoring salinity of surface waters. The objective of this study to ascertain the possibility of salinity indices that extract from Landsat 8 operational land imager (OLI) to detect TDS value in Shatt al-Arab river.

\section{Materials and Methods}

In this study two kind of data were used, in situ data and satellite data, for evaluation and comparing the salinity levels in surface waters. The methodology of this study concerns the study of the correlation between spectral band values and the salinity level of Shatt al-Arab. The ground reference data were collected in the days of 9 Dec. 2015, 27 Jan. 2017, and 28 Sep. 2018 (as in Table 1) which were coincident with the acquisition of respective OLI images (Table 2). In fact, due to technical limitations, satellite remote sensing still faces certain challenges in real-time data collection. A minor difference between the field sampling time and time of capturing the image (about hours or minutes) does not affect the accuracy of the analysis results because the concentration change of TDS in several hours is very rare (Abdullah et al. 2017).

\subsection{Study Area}

The Shatt al-Arab river is formed by the confluence of the Tigris and the Euphrates Rivers at Qurna town located in the southern part of Iraq; then, it discharges its water to the Arabian Gulf. Figure 1 shows the sample collection locations from the Shatt al-Arab river near the
Table 2 Properties of Landsat 8 OLI images

\begin{tabular}{|c|c|c|c|}
\hline Images properties & 2015 & 2017 & 2018 \\
\hline Path and raw of the scene & \multicolumn{3}{|l|}{$\begin{array}{l}166 / 39 \\
166,039 \\
166,039\end{array}$} \\
\hline Sensor & \multicolumn{3}{|c|}{ Operational Land Imager (OLI) } \\
\hline Bands used in this study & \multicolumn{3}{|c|}{$\begin{array}{l}\text { Blue (2), green (3), red (4), and NIR } \\
\quad(5)\end{array}$} \\
\hline Band number & \multicolumn{3}{|c|}{$\begin{array}{l}\text { B-2 Visible }(0.450-0.51 \mu \mathrm{m}) 30 \mathrm{~m} \\
\text { B-3 Visible }(0.53-0.59 \mu \mathrm{m}) 30 \mathrm{~m} \\
\text { B-4 Red }(0.64-0.67 \mu \mathrm{m}) 30 \mathrm{~m} \\
\text { B-5 Near-Infrared }(0.85-0.88 \mu \mathrm{m}) \\
\quad 30 \mathrm{~m}\end{array}$} \\
\hline Reflectance-add-band* & \multicolumn{3}{|l|}{-0.1} \\
\hline Reflectance-mult_band* & \multicolumn{3}{|l|}{$2 \mathrm{e}-05$} \\
\hline Time capture & $2015 / 12 / 09$ & $2017 / 1 / 27$ & $2018 / 9 / 28$ \\
\hline Sun elevation & $33.51^{\circ}$ & $43.47^{\circ}$ & $52.53^{\circ}$ \\
\hline
\end{tabular}

${ }^{*}$ Rescaling factors in the metadata file of Landsat data. The details explained in Eq. 1

center of Basrah governorate. The study area spans over $120 \mathrm{~km}$ of total the river length of $195 \mathrm{~km}$.

\subsection{Water Sampling and Satellite Image}

TDS values of the total 18 samples measured with electrical conductivity EC meter from six locations (stations) of river (Fig. 1). Samples have been selected from in situ periodic data of TDS which collected per day through 3 years 2015, 2017, and 2018 (Table 1). The time of collecting field data and satellite image data (which was in 9 December 2015, 27 January 2017, and 28 September 2018), was simulated to evaluate the relationship between field TDS values and band values. Three images of Landsat 8 OLI have been acquired from the United States Geological Survey (USGS) website (USGS 2019). The gap in the data (year 2016) is not

Table 1 Samples position and TDS measurements with different years

\begin{tabular}{llllll}
\hline Station & Latitude & Longitude & $\begin{array}{l}\text { 9 Dec. 2015 } \\
\text { TDS (mg/l) }\end{array}$ & 27 Jan. 2017 & 28 Sep. 2018 \\
\hline Qurna & $47^{\circ} 45^{\prime} 38^{\prime \prime}$ & $31^{\circ} 00^{\prime} 14^{\prime \prime}$ & 1950 & 800 & 800 \\
Labani & $48^{\circ} 00^{\prime} 21^{\prime \prime}$ & $30^{\circ} 46^{\prime} 29^{\prime \prime}$ & 4560 & 4000 & 23,300 \\
City Centre & $47^{\circ} 55^{\prime} 77^{\prime \prime}$ & $30^{\circ} 83^{\prime} 23^{\prime \prime}$ & 1900 & 960 & 1270 \\
Kateban & $47^{\circ} 75^{\prime} 90^{\prime \prime}$ & $30^{\circ} 62^{\prime} 57^{\prime \prime}$ & 1900 & 2000 & 7400 \\
Cornash & $47^{\circ} 84^{\prime} 73^{\prime \prime}$ & $30^{\circ} 51^{\prime} 72^{\prime \prime}$ & 5400 & 4000 & 19,650 \\
Sahan & $48^{\circ} 24^{\prime} 07^{\prime \prime}$ & $30^{\circ} 33^{\prime} 29^{\prime \prime}$ & 1850 & 8000 & 37,110 \\
\hline
\end{tabular}



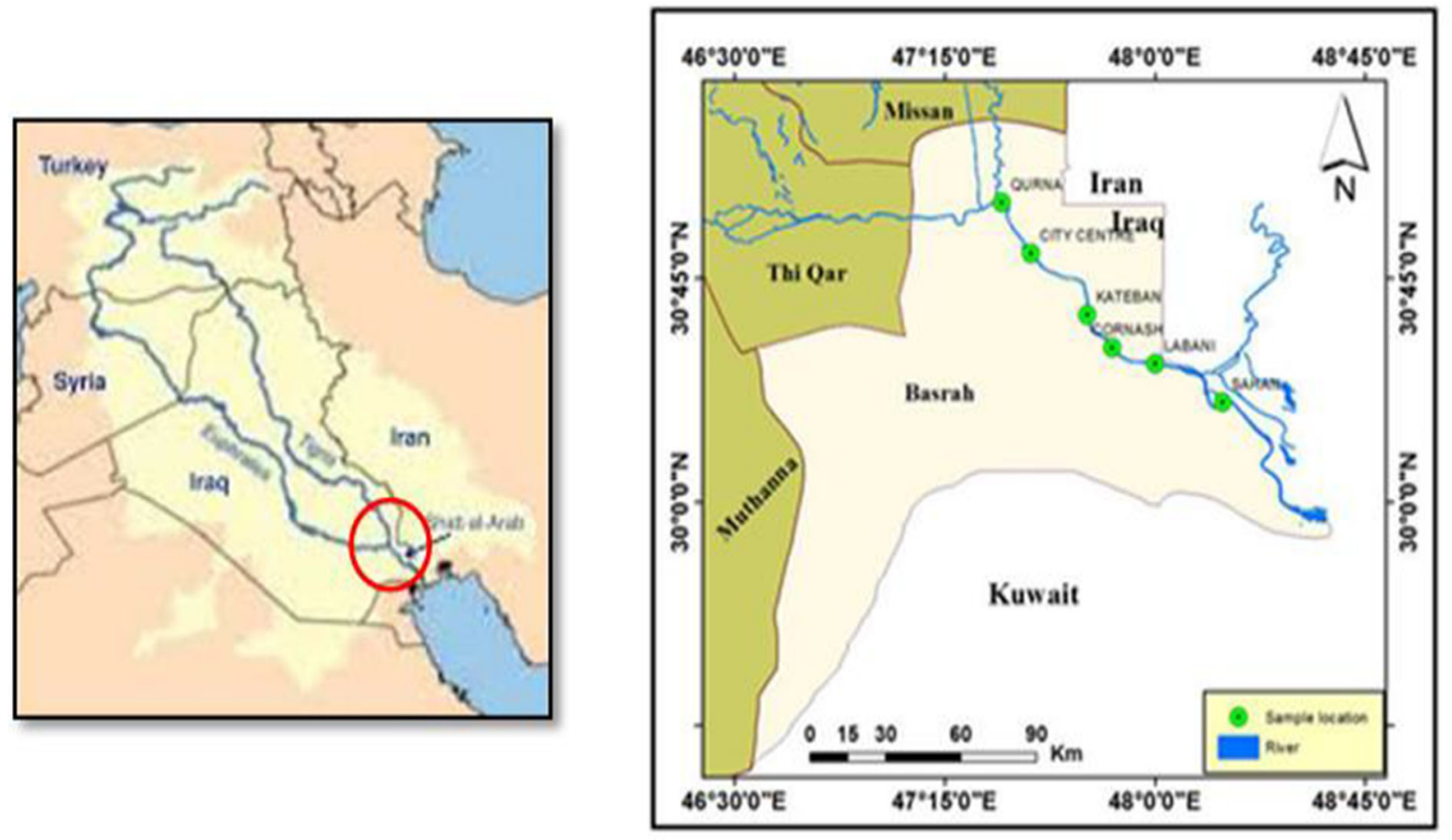

Fig. 1 Shatt al-Arab map with six sampling stations

included in this research, because the condition of the simulation between spectral and ground data was not available.

As shown in Table 1, there is an increase in the salt in the second station (Labani) compared with the first station (Qurna). The extremism in the concentrations of salts is due to the discharges of the Suwaib River into Shatt al-Arab river after Qurna town; the high salinity comes from the Suwaib river as a result of cutting off the river via regulation and diversion hydraulic structures by the Iran government. While the increase of the salt in the Sihan station is influenced by the tide phenomena of the Arab Gulf (Rahi 2018). In general, salinity increase in Shatt al-Arab may be attributed to salinity increase in the lower parts of Euphrates and Tigris rivers and decrease of freshwater inflow to the Shatt, in addition to an increase in the temperature and evaporation rate (Rahi 2018).

\subsection{Data Set and Image Pre-processing}

The OLI data are used in the present study to obtain mathematical models for estimating the salinity of water depending on the spectral reflectance of it. The OLI images were converted to a Universal Transverse
Mercator (UTM) coordinate system, using World Geodetic System (WGS) 1984 datum, assigned to north UTM zone 39 (Fig. 2, Table 2).

RS data processing was performed using ERDAS IMAGINE V.9.2 and ArcGIS software v. 10.6. The images dataset was obtained with four bands including band $2,3,4$, and 5 representing blue, green, red, and (nearinfrared) NIR band respectively, as shown in Fig. 3.

The processing consists of two steps, including (1) geometric correction and (2) atmospheric correction. The brightness values of satellite images "which recorded by sensor as digital number DN values" were converted to reflectance values using the raster calibration tool in Arc GIS. This processing is important for environmental studies of surface water. Extracting information from Landsat images, included converted the digita value of each pixel (small unite of image) to reflectance value according to the following equation $(1,2)$ :

$\rho \lambda^{\prime}=M^{P} \times Q c a l+A^{P}$

where,

$p \lambda^{\prime}$ : top-planetary spectral reflectance, without correction for solar angle 
Fig. 2 Satellite Image is modified to show six sampling locations along the Shatt al-Arab river

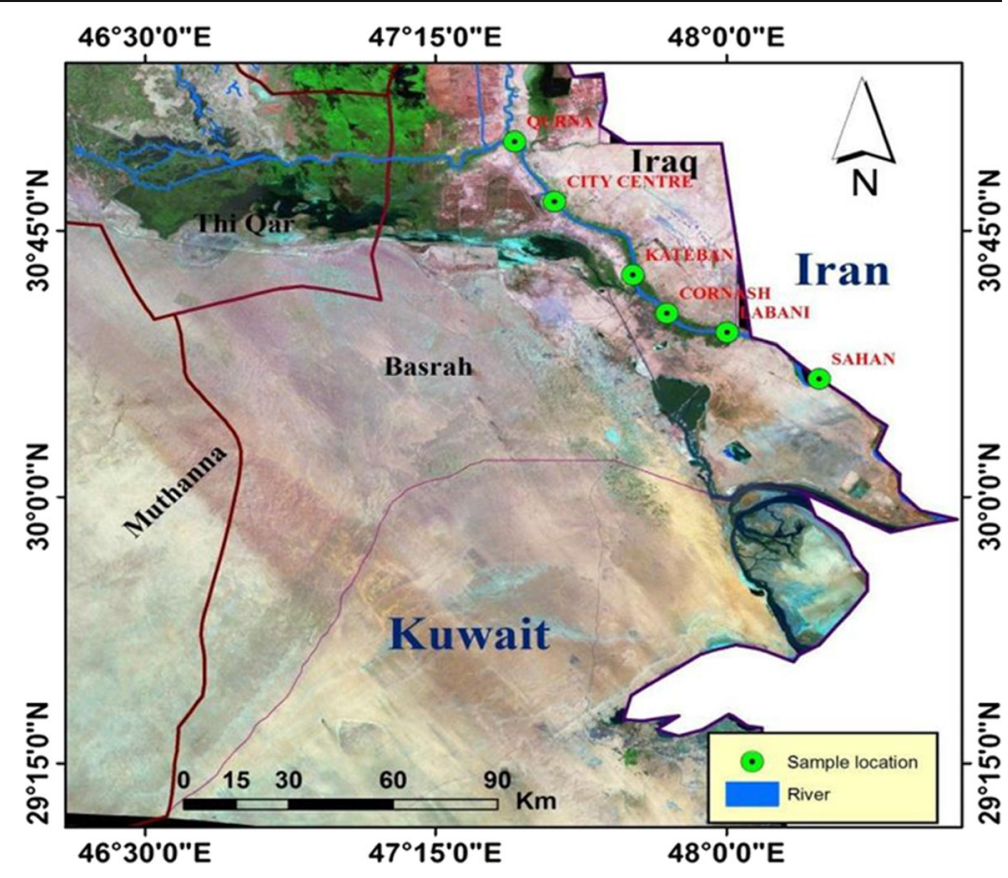

$M^{P}$ : reflectance multiplicative rescaling factor from the metadata for the band (REFLECTANCE MULT_BAND_ $\mathrm{x}$, where $\mathrm{x}$ is the band number $)=$ 2.0000e-05 (Table 2)

$A^{P}$ : reflectance additive rescaling factor from the metadata for the band (REFLECTANCE ADD_BAND_ $\mathrm{x}$, where $\mathrm{x}$ is the band number $)=-0 . \overline{1}$ (Table 2)

Qcal: quantized and calibrated standard product pixel values $(\mathrm{DN})$

Correction for the solar elevation angle represented important factor to calculate TOA reflectance with a correction for the sun angle as in the formula below:

$P \lambda=\rho \lambda^{\prime} / \sin (\theta)$

where:

$\mathrm{P} \lambda=$ top-of-atmosphere planetary reflectance

$\theta=$ solar elevation angle (from the MTL file of the OLI raw data)

\subsection{Multi-spectral Salinity Index}

The radiance rescaling factors in the metadata file of OLI data were used to convert the radiance of OLI image to TOA spectral reflectance by applying Eqs. 1 and 2. To study the water parameter, it is necessary to choose a spectral package that is highly reflective, which is important to understand the relationship between these parameters and corresponding spectral bands. Also water body classification is the first step to assess the water quality in remote sensing. Generally, there are three potential water body reflectances: water surface reflectance, bottom reflectance of water, and volume reflectance. However, volume reflectance includes information relating to water quality. On the other hand, Clearwater ( $>2 \mathrm{~m}$ deep) has very low reflectance which is confined to the (Vis) bands (blue, green, red). Shallow water $(<2 \mathrm{~m}$ deep) transmits significant amounts of NIR spectrum (Mustafa et al. 2017). Minerals, salts, sediments, and other components affect the quality of the water. For demonstrating the water element, a spectral range should be adopted that gives higher reflectance. In coastal water, the signature measured above the water is influenced by variations arising from changes in water depth, bottom type, and scattering and absorption in the water column (by chlorophyll, suspended sediments, colored dissolved organic matter, etc.) (Howari 2003). Several salinity indices were selected for this study based on visible and NIR infrared bands from comprehensive literature reviewed and calculated using its equations (Lyon et al. 1988; Abdullah et al. 2017). These indices are calculated using equations, as shown in Table 3. Different rasters were extracted and built up using salinity index equations, then examined to derive the TDS values from the selected stations. 

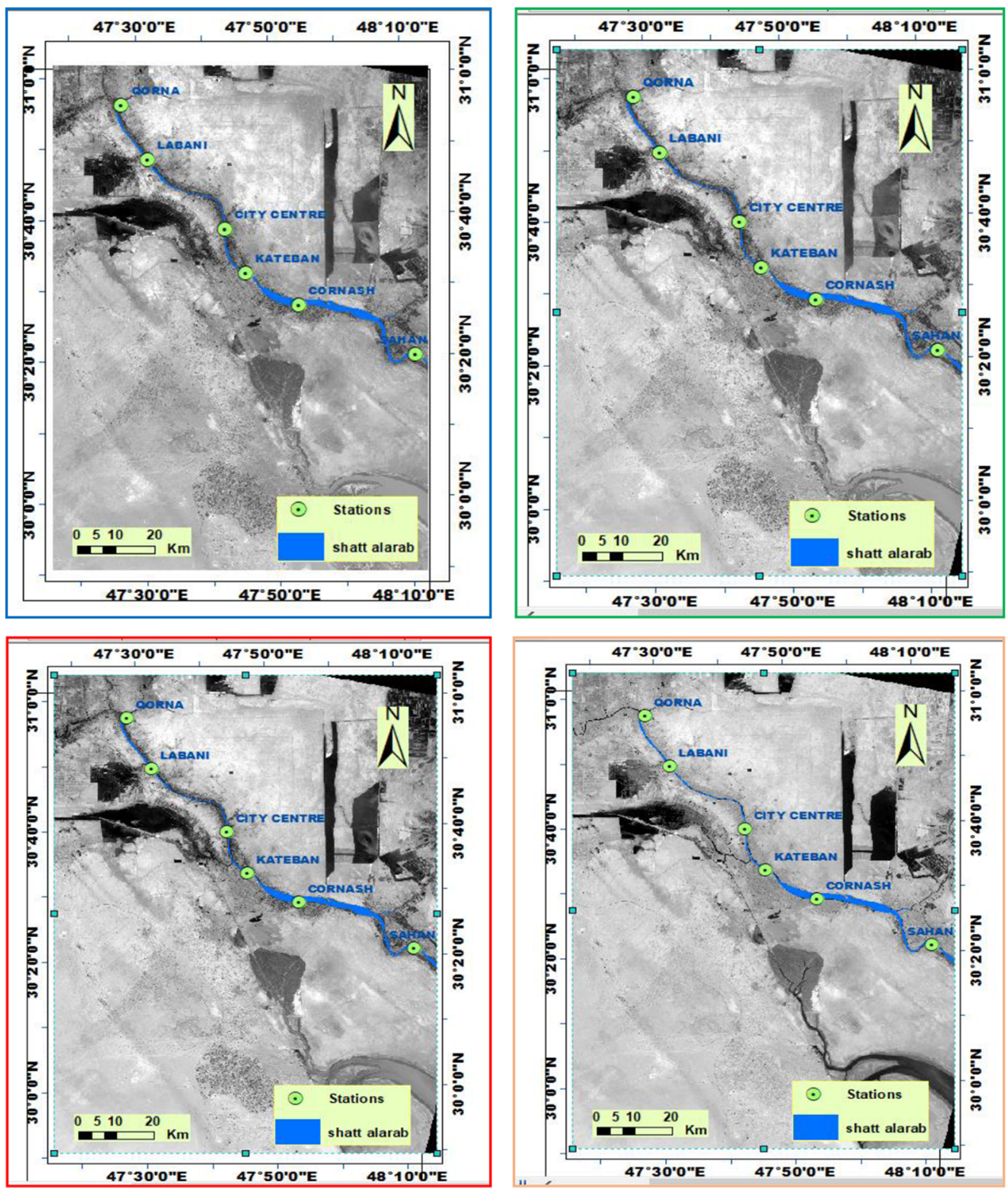

Fig. 3 Study area images in four bands of the Landsat 8 OLI sensor for 2017: Bands No. 2 (blue), 3 (green), 4 (red), and 5 (NIR)

The Raster Calculator tool was applied to create and execute a map algebra for the salinity index for three observations $(2015,2017$, and 2018). The range values in the output raster of the indices were between $(-1$ to + 1 ). The spectral signature value of the water reflectance has the characteristic as a general reduction in 
Table 3 The most spectral indices used for this study (Morshed et al. 2016)

\begin{tabular}{ll}
\hline Indices & Equation \\
\hline Brightness index 1 & $\sqrt{R^{2}+N I R^{2}}$ \\
Brightness index 2 & $\sqrt{G^{2}+N I R^{2}}$ \\
Salinity index 1 & $\sqrt{R \times B}$ \\
Salinity index 2 & $\sqrt{G \times B}$ \\
Salinity index 3 & $\sqrt{R^{2}+G^{2}}$ \\
Salinity index 4 & $\sqrt{R^{2}+G^{2}+N I R^{2}}$ \\
Salinity index 5 & $G \times R$ \\
Salinity index 6 & $\sqrt{G^{2} \times N I R^{2}}$ \\
\hline
\end{tabular}

Where $\mathrm{R}$, red $=$ band $4 ; \mathrm{B}$, blue $=$ band $2 ; \mathrm{G}$, green $=$ band $3 ; \mathrm{NIR}$, near infrared $=$ band 5

reflectance with increasing wavelength in the VIS and NIR wavebands (band 2-band 5) which are represented important bands for water quality parameters.

\subsection{Correlation and Regression Analysis}

The spectral band values at each measurement station were extracted from images for use as independent variables in bivariate regression models (Lusch 1999; Saleh 2017). Only the single pixel value (the pixel value is a single number that represents the brightness of the pixel) for each sampling station was extracted. To assess the nature and strength of the relationships, the correlation between the VIS and NIR spectral bands of Landsat-8 images and the in situ TDS measurements were investigated by calculating the Pearson correlation ( $r$ ) using correlation coefficient and using simple linear regression $\left(R^{2}\right)$ to find out the highly correlated value between the two sets of variables (spectral and ground data for six sampling stations) then choosing the best index.

\section{Results}

After modified the DN values of satellite images to reflection values using the geometric and atmospheric correction process, the calculation raster build-up using salinity index equations. The spectral reflectance values
Table 4 Reflectance values for salinity raster's (images) conducted from three important salinity indices (SI) at six stations for 2015/12/09

\begin{tabular}{llll}
\hline Station & SI- $1=\sqrt{\mathrm{R} \times \mathrm{B}}$ & $\mathrm{SI}-2=\sqrt{\mathrm{G} \times \mathrm{B}}$ & $\mathrm{SI}-5=\mathrm{G} \times \mathrm{R}$ \\
\hline City Centre & 0.1031 & 0.1282 & 0.0088 \\
Kateban & 0.1108 & 0.1330 & 0.0125 \\
Cornash & 0.0986 & 0.1184 & 0.0074 \\
Qurna & 0.1407 & 0.1566 & 0.0194 \\
Labani & 0.1068 & 0.1244 & 0.0087 \\
Sahan & 0.1595 & 0.1566 & 0.0260 \\
\hline
\end{tabular}

SI salinity index. $\mathrm{R}$, red $=$ band $4 ; \mathrm{B}$, blue $=$ band $2 ; \mathrm{G}$, green $=$ band 3

acquired from derived salinity raster for six stations are shown in Tables 4, 5, and 6.

Values of $r$ and $R^{2}$ were acquired between the spectral values captured from salinity index rasters produced in this study and TDS of field measurement to find out the highly correlated values and select the best index (Table 7), which appears to be SI-2. A very high accuracy was obtained for TDS field data in the six stations and SI-2 with $r$ value of $0.70,0.97$, and 0.71 in 2015, 2017 , and 2018 respectively. These values appear to be encouraging for predicting salinity through the spectral index, while a second good result was found between TDS and SI- 1 with $r$ value of $0.61,0.86$, and 0.65 for the years 2015, 2017, and 2018 respectively. Acceptable values of correlation coefficient $R^{2}$ were also found by using liner regression between the two sets of variables (spectral and ground data for six sampling station) to confirm the accuracy of results for SI-2 and SI-1 indices (Table 7).

Table 5 Reflectance values for salinity rasters (images) conducted from three important indices at six stations for 2017/1/27

\begin{tabular}{llll}
\hline Station & SI-1 $=\sqrt{\mathrm{R} \times \mathrm{B}}$ & $\mathrm{SI}-2=\sqrt{\mathrm{G} \times \mathrm{B}}$ & $\mathrm{SI}-5=\mathrm{G} \times \mathrm{R}$ \\
\hline City Centre & 0.0611 & 0.0705 & 0.0039 \\
Kateban & 0.0588 & 0.0682 & 0.0035 \\
Cornash & 0.0570 & 0.0666 & 0.0033 \\
Qurna & 0.0642 & 0.0698 & 0.0031 \\
Labani & 0.0555 & 0.0668 & 0.0030 \\
Sahan & 0.0494 & 0.0574 & 0.0022 \\
\hline
\end{tabular}

SI salinity index. $\mathrm{R}$, red $=$ band $4 ; \mathrm{B}$, blue $=$ band $2 ; \mathrm{G}$, green $=$ band 3 
Table 6 Reflectance values for salinity rasters (images) conducted from three important indices at six stations for 2018/9/28.

\begin{tabular}{llll}
\hline Station & SI-1 $=\sqrt{\mathrm{R} \times \mathrm{B}}$ & $\mathrm{SI}-2=\sqrt{\mathrm{G} \times \mathrm{B}}$ & $\mathrm{SI}-5=\mathrm{G} \times \mathrm{R}$ \\
\hline City Centre & 0.0730 & 0.0917 & 0.0054 \\
Kateban & 0.0518 & 0.0673 & 0.0024 \\
Cornash & 0.0395 & 0.0542 & 0.0011 \\
Qurna & 0.0869 & 0.0995 & 0.0080 \\
Labani & 0.0370 & 0.0526 & 0.0011 \\
Sahan & 0.0559 & 0.0666 & 0.0029 \\
\hline
\end{tabular}

SI salinity index. R, red $=$ band $4 ; \mathrm{B}$, blue $=$ band $2 ; \mathrm{G}$, green $=$ band 3

Our results confirm that the (SI-2) and (SI-1) were suitable indices for salinity investigation in the Shatt alArab river. For detecting the TDS level of surface water of the Shatt al-Arab River, the best correlation results of the salinity indices from OLI image of 2017 were chosen to generate three equations through linear regression analysis as shown in Fig. 4 and Table 8, which illustrate the best prediction models of TDS that may be used to estimate the salinity along the river.

\section{Discussion}

The result of this study was comparable to another study by Ferdous et al. (2019); they reported that the salinity level (TDS level) of surface water in Coastal Bangladesh can be easily detected by using different band compositions of Landsat 8 OLI. Seven band compositions (blue, green, red, blue and green, blue and red, green and red, blue and green and red) have been identified according to regression analysis with field values (Ferdous et al. 2019). They concluded that the blue, green, and red bands were helpful to predict the TDS level of coastal surface water from Landsat 8 OLI images, which makes the monitoring of water quality more appropriate (Ferdous et al. 2019). Such significant relationships were established between Landsat TM with ground referenced data in several studies. Baban (1993) produced regression models to predict and map a water parameter including salinity in the Norfolk Broads in East Anglia, England. He found that the measuring of water quality parameters by using satellite imagery techniques is time saving and gives a synoptic view of a water body. Also, Zhuiykov (2012) states that the multiple linear models were used to successfully predict the water quality parameters in south-east Australia, using Landsat MSS data. Another study conducted for the water quality of $\mathrm{Al}$ Gharraf stream within the city of Nasiriya-Iraq, found positive strong correlations between the reflectance of Landsat images and the water parameters. In this study five water indices from OLI sensor at 2017 (normalized difference water index (NDWI), modification of normalized difference water index (MNDWI), normalized difference moisture index (NDMI), water ratio index (WRI), and automated water extraction index (AWEI)) have been used to assess the nature and strength of the relationships with field data of eleven parameters (Mustafa et al. 2017). Abd et al. (2017) also found that the physical and chemical parameters in the water surface cannot be calculated using vegetation index from Landsat-8 (OLI) images and the linear relationship $(R)$ between the two variables is not significant. Comparing with current study, both (Mustafa et al. 2017, Abd et al. 2017) found an inappropriate correlation between water indices of spectral images and TDS measurement.

\section{Conclusions}

At the present time, effective techniques such as RS tools are required to develop solutions for water resources problems and to assess water qualities in large scale. This paper

Table 7 Pearson correlation $(r)$ and coefficient of determination values $\left(R^{2}\right)$ between field data and spectral data from selected salinity indices images (raster)

\begin{tabular}{|c|c|c|c|c|c|c|}
\hline \multirow[t]{2}{*}{ Salinity index (SI) } & \multicolumn{2}{|c|}{ TDS field data 2015} & \multicolumn{2}{|c|}{ TDS field data 2017} & \multicolumn{2}{|c|}{ TDS field data 2018} \\
\hline & $r^{*}$ & $R^{2 * *}$ & $r^{*}$ & $R^{2 * *}$ & $r^{*}$ & $R^{2 * *}$ \\
\hline Salinity index 1 & 0.610 & 0.560 & 0.86 & 0.940 & 0.650 & 0.850 \\
\hline Salinity index 2 & 0.700 & 0.88 & 0.970 & 0.945 & 0.710 & 0.792 \\
\hline Salinity index 5 & 0.560 & 0.440 & 0.180 & 0.740 & 0.630 & 0.765 \\
\hline
\end{tabular}

*Explained the simple linear regression. **Explained variability in the data set 
Fig. 4 Regression lines for salinity indices SIs (SI-1A, SI-2 $\mathrm{B}$, and SI-5 C) versus TDS values for 2017
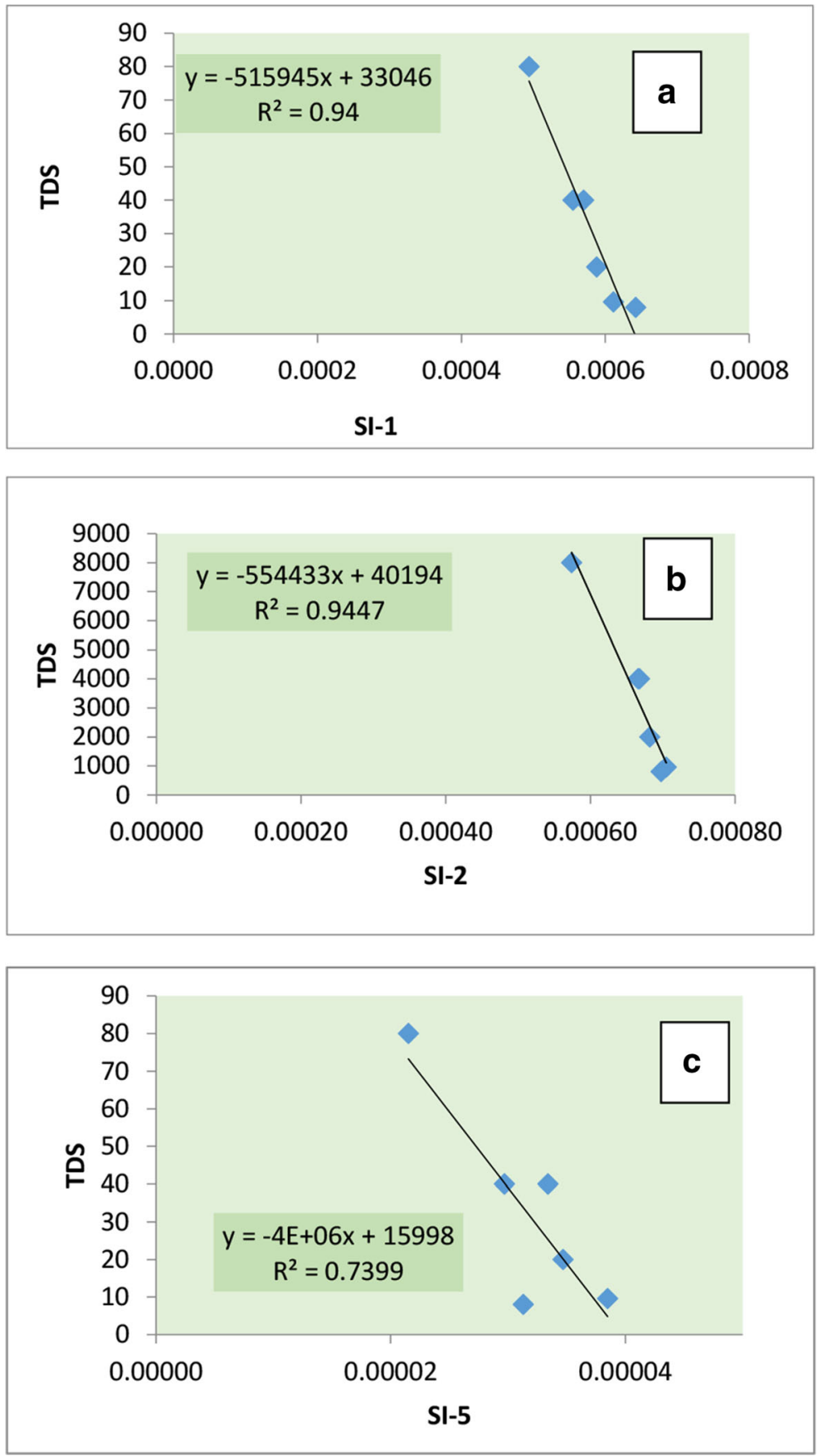

has presented the potential of integrating Landsat 8 OLI data analysis and field survey data. Satellite data and water samples were collected nearly simultaneously to assess the salinity of the Shatt al-Arab river in Basra province, Iraq.

The efficiency of the proposed algorithms was investigated based on the coefficient of determination values. The current research indicated that despite the variation in statistical response, a good correlation existed between SI-2 acquired from OLI image and six field samples with $r$ value of $0.70,0.97$, and 0.71 and $R^{2}$ of $0.88,0.95$, and 0.79 between field data with spectral data of SI-2 derived from the green and blue bands of Landsat images obtained in 3 years $(2015,2017$, and 2018) respectively. The correlations between different 
Table 8 Best prediction models of TDS through the spectral bands of salinity index 1,2, and 5, for six sampling stations

\begin{tabular}{lll}
\hline Landsat 8 OLI image & Prediction model & $R^{2}$ \\
\hline Salinity index 1 & TDS $=-515,945($ SI-1) $+33,046$ & 0.94 \\
Salinity index 2 & TDS $=-554,433($ SI-2) $+40,194$ & 0.95 \\
Salinity index 5 & TDS $=-4$ e6 (SI-5) $+15,998$ & 0.74
\end{tabular}

indices with TDS in six stations along the river were calculated using regression analysis. Highly correlated for regression values $R^{2}$ of $0.94,0.95$, and 0.74 for SI- 1 , SI-2, and SI-5 from OLI image of 2017, respectively, were found between reflection values of salinity index images and field data. The results confirmed that the SI2 and SI-1 were suitable indices for investigating effects of salinity in the Shatt al-Arab river. Elaboration of OLI data using spectral index algorithms provides a powerful tool for retrieving salinity in the surface waters. We hope our study could help the local and central authorities in future monitoring of the salinity levels in rivers. Such monitoring could predict potential freshwater scarcities and prevent health hazards for local inhabitants.

Funding Open access funding provided by Lulea University of Technology.

\section{Compliance with Ethical Standards}

Conflict of Interest The authors declare that they have no conflict of interest.

Open Access This article is licensed under a Creative Commons Attribution 4.0 International License, which permits use, sharing, adaptation, distribution and reproduction in any medium or format, as long as you give appropriate credit to the original author(s) and the source, provide a link to the Creative Commons licence, and indicate if changes were made. The images or other third party material in this article are included in the article's Creative Commons licence, unless indicated otherwise in a credit line to the material. If material is not included in the article's Creative Commons licence and your intended use is not permitted by statutory regulation or exceeds the permitted use, you will need to obtain permission directly from the copyright holder. To view a copy of this licence, visit http://creativecommons.org/licenses/by/4.0/.

\section{References}

Abd, M. H., Mustafa, T. M., Hassoon, K. I., \& Hussain, M. H. (2017). Using vegetation indices (Ndvi, Rvi, Ipvi, and Dvi) to detect physical and chemical parameters from Landsat-8(Oli) image when pixel mixing soil, vegetation, and water. Scholars Journal of Engineering and Technology, 5-11, 624-628.

Abdullah, H. S., Mahdi, M. S., \& Ibrahim, H. M. (2017). Water quality assessment models for Dokan Lake using Landsat 8 OLI satellite images. Journal of Zankoy Sulaimani, Pure and Applied Sciences, 19-3-4, 25-44.

Baban, S. M. J. (1993). Detecting water quality parameter in Norfolk Broads, U.K. using Landsat imagery. International Journal of Remote Sensing, 14, 1247-1267.

Dogliotti, A. I., Ruddick, K. G., Nechad, B., Doxaran, D., \& Knaeps, E. (2015). A single algorithm to retrieve turbidity from remotely-sensed data in all coastal and estuarine waters. Remote Sensing of Environment, 156, 157-168.

Ferdous, J., Rahman, M. T. U., \& Ghosh, S. K. (2019) Detection of total dissolved solids from Landsat 8 OLI image in coastal Bangladesh. Proceedings of the $3^{\text {rd }}$ International Conference on Climate Change , 3, (pp. 35-44).

González-Márquez, L. C., Torres-Bejarano, F. M., RodríguezCuevas, C., Torregroza-Espinosa, A. C., \& SandovalRomero, J. A. (2018). Estimation of water quality parameters using Landsat 8 images: application to Playa Colorada Bay, Sinaloa, Mexico. Applied Geomatics, 10, 147-158.

Härmä, P., Vepsäläinen, J., Hannonen, T., Pyhälahti, T., Kämäri, J., Kallio, K., Eloheimo, K., \& Koponen, S. (2001). Detection of water quality using simulated satellite data and semi-empirical algorithms in Finland. Science of the Total Environment, 268, 107-121.

Hellweger, F. L., Schlosser, P., Lall, U., \& Weissel, J. K. (2004). Use of satellite imagery for water quality studies in New York Harbor. Estuarine, Coastal and Shelf Science, 61, 437-448.

Howari, F. M. (2003). The use of remote sensing data to extract information from agricultural land with emphasis on soil salinity. Soil Research, 41, 1243-1253. https://doi. org/10.1071/SR03033.

Karakaya, N., Evrendilek, F., Aslan, G., Gungor, K., \& Karakas, D. (2011). Monitoring of lake water quality along with trophic gradient using Landsat data. International journal of Environmental Science and Technology, 8, 817-822.

Kulkarni, A. (2011). Water quality retrieval from Landsat TM imagery. Procedia Computer Science, 6, 475-480. https://doi.org/10.1016/j.procs.2011.08.088.

Lim, H. S., MatJafri, M. Z., Abdullah, K., Alias, A. N., Wong, C. J., Mustapha-Rosli, M. R., \& Saleh, N. M. (2009) Water quality mapping using Landsat TM imagery. Visual Information Processing XVIII, The International Society for Optical Engineering Source, Florida, USA, 7341 734107-1.

Lusch, D. P. (1999). Introduction to environmental remote sensing. East Lansing: Center for Remote Sensing and GIS Michigan State University.

Lyon, J. G., Bedford, K. W., Yen, C. C. J., Lee, D. H., \& Mark, D. J. (1988). Determinations of suspended sediment concentrations from multiple day Landsat and AVHRR data. Remote Sensing of Environment, 25, 107-115.

Mohamed, M. A., Hussein, A. S., \& Lazem, F. L. (2016). Appraisal of some water quality criteria of the Shatt AlArab River by applying geographical information system (GIS). GJBAHS, 5, 43-53.

Morshed, M. M., Islam, M. T., \& Jamil, R. (2016). Soil salinity detection from satellite image analysis: an integrated 
approach of salinity indices and field data. Environmental Monitoring and Assessment, 188, 119. https://doi. org/10.1007/s10661-015-5045-X.

Mustafa, T. M., Hassoon, K. I., Hussain, H. M., \& Abd, M. H. (2017). Using water indices (NDWI, MNDWI, NDMI, WRI and AWEI) to detect physical and chemical parameters by apply remote sensing and GIS techniques. International Journal of Research-Granthaalayah, 5, 117-128. https://doi.org/10.5281/zenodo.1040209.

Pásler, M., \& Komárková, J. (2016). Utilization of Landsat data for water quality observation in small inland water bodies. The International Archives of the Photogrammetry, Remote Sensing and Spatial Information Science, XLI-B8, 373-377.

Rahi, K. A. (2018). Salinity management in the Shatt Al-Arab River. International Journal of Engineering \& Technology, 7(4.20), 128-133.

Saleh, A. M. (2017). Evaluation of different soil salinity mapping using remote sensing indicators and regression techniques, Basrah, Iraq. Journal of American Science, 13, 85-89.

Schofield, R. O. B. E. R. T., Thomas, D. S., \& Kirkby, M. J. (2001). Causal processes of soil salinization in Tunisia, Spain and Hungary. Land Degradation \& Development, 12, 163181. https://doi.org/10.1002/ldr.446.
USGS. National Land Imaging Program. Science for changing world. Landsat-A Global Land-Imaging Mission. Available online: http://remotesensing.usgs.gov. Accessed 9 June 2019.

Wu, J., Vincent, B., Yang, J., Bouarfa, S., \& Vidal, A. (2008). Remote sensing monitoring of changes in soil salinity: a case study in Inner Mongolia, China. Sensors, 8, 7035-7049. https://doi.org/10.3390/s8117035.

Yusop, S. M., Abdullah, K., San, L. H., \& Bakar, M. N. A. (2011) Monitoring water quality from Landsat TM imagery in Penang, Malaysia. Proceeding of the 2011 IEEE International Conference on Space Science and Communication (IconSpace) (pp. 249-253). Piscataway: IEEE.

Zhuiykov, S. (2012). Solid-state sensors monitoring parameters of water quality for the next generation of wireless sensor networks. Sensors and Actuators B: Chemical, 161(1-3), 1-20.

Publisher's Note Springer Nature remains neutral with regard to jurisdictional claims in published maps and institutional affiliations. 